\title{
EXPOSURE TO COMPLEX ENVIRONMENTAL HEALTH Challenges: Agent Orange and Sodium Dichromate
}

\author{
CHERYL G. SULLIVAN*
}

\section{INTRODUCTION}

American military personnel face danger not only from the weaponry of hostile forces but from exposure to occupational and environmental hazards as well. In two notable cases - exposure to Agent Orange during the Vietnam War and sodium dichromate during Operation Iraqi Freedom-American military leadership neither identified the risks nor diagnosed or treated the effects of such exposure. A sense of urgency exists to identify policy interventions by the public and private sectors to address the potential for future exposure of service members to environmental and occupational hazards given emerging threats. ${ }^{1}$ That exposure to Agent Orange and sodium dichromate was mishandled as a function of several readily identifiable factors.

Complexity theory ${ }^{2}$ can inform risk management ${ }^{3}$ of complex environmental

* was the Chief Executive Officer of the American Academy of Nursing (2010-2018), the Deputy Chief of Staff for Policy for Senator Evan Bayh (2005-2010), and the Cabinet Secretary of the Indiana Family and Social Services Administration (1993-1997 and 2003-2004). Is a Ph.D. Candidate at Indiana University, Paul H. O'Neill School of Public and Environmental Affairs. Email: CherylSull@aol.com, Address: 5854 Lawton Loop West Drive, Indianapolis, Indiana 46216. Phone: (317) 331-9392

1. Dep't of Defense, Summary of the 2018 National Defense Strategy of the United States of America: Sharpening the American Military's Competitive Edge 2-3 (2018) (cautions that "revisionist powers and rogue regimes are competing across all dimensions of power. They have increased efforts short of armed conflict by expanding coercion to new fronts, violating principles of sovereignty, exploiting ambiguity, and deliberately blurring the lines between civil and military goals." Further, "states are the principal actors on the global stage, but non-state actors also threaten the security environment with increasingly sophisticated capabilities. Terrorists, trans-national criminal organizations, cyber hackers and other malicious non-state actors have transformed global affairs with increased capabilities of mass disruption").

2. Neil Pearce \& Franco Merletti, Complexity, simplicity, and epidemiology, 35 INT'L. J. EPIDEMIOLOGY, 515, 518 (2006). "The key concepts of complexity theory are self-organization, adaptation, upheavals at the edge of chaos, the unpredictability of the effects of small changes in initial conditions, and the existence of simplicity at some levels while chaos exists at others."

3. See Dep't of the Army, Army Techniques Publication No. 5-19: Risk MANAGEMENT, 1-1 (Apr. 14, 2014), https:/www.bits.de/NRANEU/others/amd-us-archive/ATP519C1\%2814\%29.pdf [https://perma.cc/E78R-YDEM]. Risk management is "the process of identifying, assessing, and controlling risks arising from operational factors and making decisions that balance risk cost with mission benefits." See Paul Slovic, Perceived Risk, Trust, and Democracy. 13 Risk ANALYSis 675, 680 (1993). "We have a long way to go in improving our risk management processes. Although we have expended massive amounts of time, money, and resources on scientific studies designed to identify and quantify risks, we have failed to expend the effort needed to learn how to manage the hazards that science is so good at identifying." 
health challenges taking into account scientific uncertainty, politics, geographic environment, economic impact, and enacted statutes and legal decisions.

First, the military is a complex adaptive system operating within an uncertain and complex environment. Competing priorities among and for the benefit of numerous actors create challenges to enact policy change. Some of the actors are soldiers who while deployed around the world have been exposed to hazardous chemicals of particular concern including Agent Orange and sodium dichromate. Other actors, whose decisions in the management of environmental health risks of the soldiers are manifested in complex feedback loops, are the leadership in the military and federal agencies. These actors operate within continuously changing organizations, each with varying degrees of innovation, such as the individual branches of the armed forces; the U.S. Departments of Defense (DOD) and Veterans Affairs (VA); the Congress; and the Judiciary.

Second, risk management is not as easy as merely presenting risk assessment information and determining to accept the risk or not. The public's perception of risk is viewed through the lens of their experience and association with known risks, ${ }^{4}$ is dependent on attitudes, beliefs, and values, ${ }^{5}$ and is interpreted through their knowledge of science. ${ }^{6}$ Conflicts between risks we ask individuals to consider versus national aggregate risks we ask society to assume to avoid potential harm must be resolved. ${ }^{7}$

Third, the expectation of scientific rigor in assessing risks to public health and the environment of military service members is limited by existing risk assessment methodologies. ${ }^{8}$ In addition, the legal definition of an adverse health effect is complicated by governing statutes passed by Congress, regulations promulgated by federal agencies, and judicial decisions on litigation under tort or contract law.

Fourth, there exists a tension between the scientific process and the legal process. The nature of scientific inquiry is slow, evolves toward evidence, and carries a degree of uncertainty. The scientific process acknowledges that adverse effects are a constant at some level, and available resources impact risk management decisions. The legal system, on the other hand, "views the

4. Vivianne H.M. Visschers et al., How Does the General Public Evaluate Risk Information? The Impact of Association and Other Risks, 23 RiSK ANALYSIS 715, 718 (2007).

5. Lennart Sjoberg, Factors in Risk Perception, 20 RisK ANALysis 1, 9 (2000).

6. Elaine Bratic Arkin, Translation of Risk Information for the Public: Message Development, in EfFective Risk Communication: The Role and Responsibility of Government and Nongovernment Organizations 127, 128 (Vincent T. Covello, David B. McCallum \& Maria T. Pavlova eds., 1989).

7. Dale Hattis, Scientific Uncertainties and How They Affect Risk Communication, in EFFective Risk Communication: The Role and Responsibility of Government and Nongovernment Organizations 117, 125 (Vincent T. Covello, David B. McCallum \& Maria T. Pavlova eds., 1989).

8. Id. at 124 .

9. Nancy S. Bryson, How Science Informs Policy Decisions: The Legal Definition of “Adverse Health Effect”, 10 Envtl. Quality Mgmt. 93, 93 (2001). 

HEALTH CHALLENGES

expression of scientific uncertainty, even in small amounts, as cause for alarm and deconstruction." ${ }^{\prime 10}$ With the presumption of innocence by industry, the high burden of proof that regulatory agencies must demonstrate delays and obstructs reasonable environmental health decision making.

Lastly, the management of uncertainty and conflict in the scientific basis of environmental health issues in the military is compounded by the unique characteristics of modern combat. The environmental risk assessment of a particular location in a war zone before the troop's arrival just may not be feasible to conduct given the timing of the mission. Strategies, as risk management options, are limited given the necessity to evaluate for both health and mission risks. Epidemiologic assessments are hampered by the content of DOD databases to identify service members with environmental exposures and the magnitude of exposure. ${ }^{11}$ The chain of command and the necessity for security create the unyielding presence of control among organizational dynamics. Also, the prolific use of private contractors in theatre to undertake what historically has been federal government roles limit access to important and critical data.

This article examines the application of complexity theory to the military environment in which servicemembers were exposed to Agent Orange in Vietnam and sodium dichromate in Iraq. Using lessons learned from risk management responses, new perspectives on how federal administrators can prepare for and manage the next risk more effectively are presented.

\section{SYSTEMS FRAMEWORK}

Drivers of emerging health threats to service members are complex and multilayered requiring not only inter- and transdisciplinary research but enhanced tools to examine the dynamic and adaptive processes of interconnected systems. "Since the design, management, and control of complex adaptive systems can involve a challenging array of distributed and interacting agents, powerful feedback loops, large time delays, and counterintuitive system behavior, this may require innovative methodological strategies," suggest Ross Hammond and Laurette Dubé. ${ }^{12}$ These strategies include the identification of the key system components, the drivers influencing the system components, and the linkages among systems including feedback loops. ${ }^{13}$

Complexity theory research is a technique that purports to explain how

10. Inst. Med., Environmental Health Sciences Decision Making: Risk MAnagement, Evidence, And Ethics: Workshop Summary 32-33 (2009).

11. Jean-Paul Chretien, Katherine C. Chretien \& Julie A. Pavlin, Long-term Health Consequences of Military Service: A Proposal to Strengthen Surveillance and Research, 131 PuB. HeAlth RePs. 834, 835 (2016).

12. Ross Hammond \& Laurette Dubé, A Systems Science Perspective and Transdisciplinary Models for Food and Nutrition Security, 109 Proc. NAT'L ACAD. SCI. 12,356, 12,357 (2012).

13. Id. at 12,356 . 
systems and organizations function. ${ }^{14}$ Jeffrey Goldstein, an editor launching the journal, Emergence: Complexity and Organization (E:CO) in 2004, claims that "complexity research has decidedly demonstrated that thriving organizations are better understood as complex[sic], nonlinear, far-from-equilibrium, and in vital contact with multiple environments." ${ }^{15}$ Organizations are no longer believed to be simple, linear, and independent systems tightly controlled to ensure stable environments. ${ }^{16}$ In their study linking complexity theory to core capabilities of continuously changing organizations, Shona Brown and Kathleen Eisenhardt concluded that "[c]ontinuously changing organizations are likely to be complex adaptive systems with semi-structures that poise the organization on the edge of order and chaos and links in time that force simultaneous attention and linkage among past, present, and future." ${ }^{17}$ In other words, complexity theory posits that systems are evolving continuously, are characterized by "partial order, and lie between the extremes of very rigid and highly chaotic organization." 18

To solve complicated health policy problems, system science borrows its methodologies from the physical and biological sciences among other disciplines to understand and generate simplified models of the real world. ${ }^{19}$ System science attempts to understand the interaction of numerous components and relationships within an environmental context of uncertainty to address a range of assumptions leading to informed policy decisions. ${ }^{20}$ For example, using a childhood obesity interventions framework, Terry Huang et al. emphasized a "systems approach can be of particular value in connecting and synthesizing the disparate threads of prevention and intervention programs and in helping to identify strategies for intervention sustainability, scalability, and reach." 21 The systems-based framework acknowledges the complexity of "factors . . . to be studied together, incorporating linkages and feedbacks that cause changes in one area to be felt elsewhere in the system."22 "Modern societies are increasingly ruled by the unwanted side effects of their differentiated subsystems, such as the economy,

14. Neil Pearce \& Franco Merletti. Complexity, simplicity, and epidemiology. 35 InT'L J. EPIDEMIOLOGY 515, 515 (2006).

15. Jeffrey Goldstein, Peter Allen \& David Snowden. Editors' Introduction, 6 EMERGENCE: COMPLEXITY AND ORG. v, v (2004).

16. Id.

17. Shona L. Brown \& Kathleen M. Eisenhardt, The Art of Continuous Change: Linking Complexity Theory and Time-Paced Evolution in Relentlessly Shifting Organizations, 42 ADMIN. SCI. Q. 1, 32 (1997).

18. Id. at 28.

19. Patricia L. Mabry, Stephen E. Marcus, Pamela I. Clark, Scott J. Leischow, and David Mendez, Systems Science: A Revolution in Public Health Policy Research 100 Am. J. Pub. HeAlth 1161, 1161 (2010).

20. Id. at 1161-62.

21. Terry T.K. Huang, Brandon Grimm \& Ross A. Hammond, A Systems-Based Typological Framework for Understanding the Sustainability, Scalability, and Reach of Childhood Obesity Interventions 40 CHILD. HEALTH CARE 253, 255 (2011).

22. Id. at 254 . 
politics, law, media, and science," concludes Julie Thompson Klein. ${ }^{23}$ "Environmental problems exemplify the new relationship of interdisciplinarity and complexity." ${ }^{24}$ Whereas interdisciplinarity may address solving a problem that necessitates input from multiple disciplines, complexity examines nonlinear and system dynamics.

Applying complexity theory to the multiple systems of linked networks responsible for risk management of the service members exposed to Agent Orange and sodium dichromate, opportunities for consensus building, ${ }^{25}$ intervention, innovation, and adaptiveness can be identified. Judith Innes and David Booher emphasize that "at the edge of chaos...innovation and dramatic shifts in activity patterns can occur, and systems can move to higher levels of performance. Such innovation, however, depends on information flows through linked networks of agents." ${ }^{26}$ Identifying potential exposure to occupational and environmental hazards, the processes among federal agencies, the Congress, and the Judiciary can be refined to respond in a timely manner to health care needs of service members.

\section{TwO COMPLEX CASES: EXPOSURE TO AGENT ORANGE AND SODIUM DICHROMATE}

\section{A. History}

The number of U.S. Vietnam veterans exposed to Agent Orange is unknown. ${ }^{27}$ Data obtained by the National Academy of Sciences (NAS) indicates that in 2018, "VA estimated that approximately 5,978,000 Vietnam-era living veterans (deployed and non-deployed defined dates of service from August 1964 to April 1975) were living." 28 NAS also reported that the results through 2000 of the Vietnam Experience Study showed that "mortality among the deployed veterans was approximately $9 \%$ higher than among the non-deployed veterans." 29

Although not likely all the approximately 2.6 million U.S. military personnel who served in Vietnam were exposed to Agent Orange, the exact exposure

23. Julie Thompson Klein, Interdisciplinarity and Complexity: An Evolving Relationship, 6 EMERGENCE: COMPLEXITY AND ORGANIZATION 2, 4 (2004).

24. Id. at 5. Klein recalls Robert Eisenstein's characterization of "the shift in scientific research from the metaphor of a microscope to [that of] a kaleidoscope." (emphasis omitted).

25. On how consensus building can be used for complex policy tasks, see Judith E. Innes \& David E. Booher, Consensus Building and Complex Adaptive Systems, 65 Am. Planning Ass'N J. 412, 413 (1999).

26. Id. at 417.

27. U.S. Gov't Accountability OfF., Use of Agent Orange In Vietnam (CED-78-158) 4 (1978), https://www.gao.gov/assets/130/123801.pdf [https://perma.cc/S5N3-5R8H].

28. Nat'L Acad. Sci. Eng'R \& Med., Veterans and Agent Orange: Update 11 (2018) 26 (2018).

29. Id. 
numbers cannot be determined. ${ }^{30}$ "Army records from the Vietnam conflict are neither complete nor well organized. This results from the Army's rapid pullout from Vietnam." 31

During the conflict, the Department of Defense (DOD) "did not consider the herbicide orange toxic or dangerous to humans" and "took few precautions to prevent exposure." ${ }^{32}$ Consistent with the Army manuals describing herbicide orange as relatively nontoxic, "[p]ersonnel subject to splashes from handling the herbicide were instructed to shower and change clothes at a convenient opportunity." 33

Under Operation "Ranch Hand" between January 1962 and September 1971, approximately 20 million gallons of the herbicide Agent Orange were "stored, mixed, handled, and loaded into airplanes" by the U.S. Air Force to destroy 500,000 acres of crops and 5 million acres of forests in South Vietnam. ${ }^{34}$ Agent Orange, ${ }^{35}$ stored in barrels with orange bands, was a formulation of 2,4Dichlorophenoxyacetic acid (2,4,-D) and 2,4,5-Trichlorophenoxyacetic acid (2,4,5-T); 2,4,5-T contained the contaminant 2,3,7,8-tetrachloro-p-dibenzo-dioxin or TCDD (commonly called "dioxin"). ${ }^{36}$ It now is known that dioxin because of its lipophilic character, is retained in human fatty tissue, is chemically stable, and is slow to metabolize. ${ }^{37}$ TCDD impacts complex cellular actions including binding of TCDD to the aromatic hydrocarbon (Ah) receptor that is an activator for gene transcription. ${ }^{38}$ In humans, the half-life of dioxin is "estimated to vary from 0.4 to more than 10 years." 39

The International Agency for Research on Cancer (IARC) classified 2,3,7,8TCDD as a Group 1, "known human carcinogen" in 1997; the U.S. Toxicology Program revised its classification based on new molecular and cellular information from "reasonably anticipated to be a human carcinogen" to "known

30. Id. at 25-26.

31. U.S. Gov't Accountability OfFice, Report by the Comptroller General of the United States: U.S. Ground Troops in South Vietnam Were in Areas Sprayed with Herbicide Orange (1979).

32. Id. at 1.

33. Id. at 4 .

34. U.S.-Vietnam Dialogue Group on Agent Orange/Dioxin 2010-2019, DeClaration and Plan of Action: Addressing the Legacy of Agent Orange in Vietnam 4 (2010), https://assets.aspeninstitute.org/content/uploads/files/content/docs/advocacy $\% 20 \mathrm{and} \% 20$ exchan ge $\% 20$ program $\% 20$ on $\% 20$ agent $\% 20$ orange/2010-6-16USVietnamDialogueGroup DeclarationandPlanofAction.pdf [https://perma.cc/QC7G-U6UY].

35. Civilian application of herbicide orange was diluted and utilized at one to four pounds per acre; the military application of 107 million pounds over six million acres was undiluted and sprayed at 12 pounds of 2,4-D and 13.8 pounds of 2,4,5-T per acre. See U.S. Gov'T ACCOUnTABILITy OfFICE, supra note 27, at 2.

36. NAT'L ACAD. SCI. ENG'R \& MED., supra note 28, at 27.

37. Nat'L Toxicology Program, 12th Report on Carcinogens 396-97 (2011).

38. Id.

39. NAT'L ACAD. SCI. ENG'R \& MED., supra note 28, at 71. 
to be a human carcinogen," in 2001; and reaffirmed "no known 'safe dose' or 'threshold' below which dioxin will not cause cancer" in $2003 .{ }^{40}$

In 1978, Congressman Ralph Metcalfe investigated the handling of herbicide exposure disability claims from Vietnam veterans and expressed concern to the U.S. Government Accounting Office (GAO) on possible long-range adverse health effects. ${ }^{41}$ In the response to Metcalfe, the GAO Comptroller noted DOD's rigid stance, "Defense officials believe that no firm link has been made between long-term adverse health effects and exposure to herbicides in Vietnam." ${ }^{\prime 2}$ DOD was undeterred even though in 1974, the National Academy of Sciences concluded, "[f]urther intensive studies are especially required with reference to the ecological distribution, the pharmacology mechanism of toxicity, possible mutagenicity, and carcinogenicity of TCDD and its possible teratogenicity in man." ${ }^{43}$

One year later after Senator Charles Percy expressed concern on behalf of Senate Permanent Subcommittee on Investigations, Comptroller General admitted, "the Department of Defense (DOD) did not consider herbicide orange toxic or dangerous to humans and took few precautions to prevent exposure to it." ${ }^{44}$ The Comptroller General recommended "the need to resolve veterans' concerns over the alleged health risks attributed to herbicides." 45

In testing the remaining stocks of Agent Orange in 1971, TCDD contaminant levels were ranging "from less than 0.05 to 47 parts per million and averaging about 2 parts per million. Current (1978) manufacturing standards for 2,4,5-T," the GAO said, "require TCDD levels be less than 0.1 part per million.."

Later in 1978, a class-action lawsuit was filed on behalf of Vietnam veterans led by a helicopter crew chief, Paul Reutershan, who believed his abdominal cancer was caused by exposure to Agent Orange during Operation "Ranch Hand." ${ }^{47}$ The U.S. Veterans Administration now recognizes seven cancers including chronic B-cell leukemia, multiple myeloma, and Hodgkin's disease and seven other illnesses including chloracne and Parkinson's to provide presumptive eligibility for disability compensation for Veterans who served in the Republic

40. Nat'L Toxicology Program, supra note 37, at 396. Dioxins \& Furans: The Most Toxic Chemicals Known to Science, ENERGy Just. Network, http://www.ejnet.org/dioxin/ [https://perma.cc/T5RW-6CTD].

41. U.S. Gov'T ACCOUNTABILITy OFF., supra note 31, at 1 .

42. U.S. GOV'T ACCOUNTABILITY OFF., supra note 27, at 5.

43. Id.

44. U.S. Gov't Accountability Office, supra note 31 , at 1 .

45. Id. at 9 .

46. U.S. General ACCOUnting OfFICE, supra note 27, at 3.

47. Richard Severo, Vietnam Veteran's Family Vows to Continue His Fight, N. Y. TIMES, (Dec. 19, 1978), https://www.nytimes.com/1978/12/19/archives/vietnam-veterans-family-vows-tocontinue-his-fight-friends-pledge.html [https://perma.cc/Y6R6-BKKL]. Clifford Terry, Shameful Story Told in 'Causes' ChICAGO TRIBUne (Nov. 10, 1986), https:/www.chicagotribune.com/ news/ct-xpm-1986-11-10-8603250025-story.html [https://perma.cc/Z462-K248]. 
of Vietnam. ${ }^{48}$

More than thirty years later, at the Qarmat Ali Water Treatment Plant in Basra, Iraq, in 2003, deployed service members provided escort and security to employees of Brown and Root Services, a division of Kellogg, Brown and Root (KBR). KBR was under contract to restore the plant to operative status. ${ }^{49}$ Approximately 830 service members, many from Oregon, West Virginia, South Carolina, and Indiana National Guard units ${ }^{50}$ potentially were exposed to sodium dichromate, a corrosion inhibitor in water. ${ }^{51}$

Sodium dichromate is an inorganic compound containing hexavalent chromium (chromium VI) known to be toxic and carcinogenic to humans. ${ }^{52}$ The route of exposure of hexavalent chromium $\left(\mathrm{Na}_{2} \mathrm{Cr}_{2} \mathrm{O}_{7}\right)$, the toxic component of sodium dichromate, is by inhalation, ingestion, or broken skin, and is readily absorbed into cells. ${ }^{53}$ Only a tiny amount of hexavalent chromium poses a serious risk. ${ }^{54}$ Max Costa, Chair, Department of Environmental Medicine, at New York University School of Medicine, testified that translating EPA's acceptable cancer risk of one cancer in one million people would limit exposure to hexavalent chromium at merely 80 picograms per cubic meter or $8 \times 10^{-5}$ ug per cubic meter, "so small that one could not begin to see it with the human eye."

Similar to the DOD's initial response to the armed forces' exposure to Agent Orange, Ellen Embry, the U.S. Deputy Assistant Secretary of Defense, Force Health Protection and Readiness, testified in 2007 before Congress to the possible exposure of the then-estimated 250 service members to sodium dichromate and polychlorinated biphenyls stating that "no specific abnormalities attributable to possible exposures were identified, and no long-term health effects are expected. ${ }^{\circ 6}$

48. Diseases Related to Agent Orange, U.S. DeP'T VeTERAnS AfFS., https://www.va.gov/ disability/eligibility/hazardous-materials-exposure/agent-orange/related-diseases/ [https://perma.cc/5L79-4BDA].

49. Inspector Gen., U.S. DeP'T Def., Exposure to Sodium Dichromate At QARmat Ali IraQ in 2003: PART II-Evaluation of ARmy AND Contractor ACtions Related to HAZARdous Industrial EXPosure, REPORT No. SPO-2011-009 1 (2011).

50. 152nd Infantry Battalion, Indiana Army National Guard

51. Qarmat Ali Water Treatment Facility, U.S. DeP'T Veterans AfFs., https://www. publichealth.va.gov/exposures/qarmat-ali/ [https://perma.cc/5PQP-UGYK].

52. Memorandum from Defense Health Board, to LTG Eric B. Schoomaker, Surgeon Gen., Army, on Defense Health Board Review of the U.S. Army Center for Health Promotion and Preventive Medicine Assessment of Sodium Dichromate Exposure at Qarmat Ali Water Treatment Plant, 2 (Dec. 19, 2008).

53. Id.

54. The Exposure at Qarmat Ali: Contractor Misconduct and the Safety of U.S. Troops in Iraq: Hearing Before the S. Democratic Policy Comm., 110th Cong. 3 (2008) (statement of Max Costa, Professor and Chairman, Dep't of Envtl. Medicine, N. Y. Univ. School of Med.).

55. Id.

56. Statement Before the H. Subcomm. on Def. Appropriations, 110th Cong. 15 (2007) (statement of Ellen Embry, Deputy Assistant Secretary of Defense, Force Health Protection and 
A soldier reported "there was a coating of orange-colored powder throughout the facility. At times, it was so thick there were at least two inches of powder on my boots." ${ }^{57}$ Edward Blacke, former KBR Health, Safety and Environmental Coordinator in Qarmat Ali, testified in 2008 that he observed, "continuous bloody noses, spitting up of blood, coughing, irritation of the nose, eyes, throat and lungs, and shortness of breath." 58

By 2011, the DOD had estimated that "nearly 1000 soldiers and U.S. Army civilian employees were exposed to sodium dichromate in the five months it took from the initial site visit until the military Command required personal protective equipment." ${ }^{\text {9 }}$ The Inspector General for the DOD concluded that "KBR did not fully comply with applicable occupational safety and health standards, and TF RIO [Task Force Restore Iraqi Oil] ${ }^{60}$ failed to enforce contractor compliance." ${ }^{61}$ And, litigation was pending by approximately 150 service members against KBR and others; the medical costs for those exposed are unknown. ${ }^{62}$

\section{RISK MANAGEMENT}

\section{A. General Considerations}

Institutional rules for risk management processes are grounded in statutory authority, regulatory authority, and judicial decisions. To address uncertainty, these rules change over time, change across public health threats, and are not stable. $^{63}$ The degree of uncertainty to reduce, the upper bounds of probability scenarios to test, the technical facts to research, and the process of communicating results are left to the policymakers. To reduce uncertainties, policymakers are put in the untenable position of often prioritizing risk assessments to be conducted on hazards with known effects but relatively low impact or on hazards with unknown effects but potentially high impact. It is important to note that risk communication is essential even if the scientific data

Readiness, Department of Defense).

57. The Exposure at Qarmat Ali: Did the Army Fail to Protect U.S. Soldiers Serving in Iraq?: Hearing Before the S. Democratic Policy Comm., 111th Cong. 1 (2009) (statement of Russell Powell, Former Staff Sergeant, West Virginia Army National Guard).

58. The Exposure at Qarmat Ali: Contractor Misconduct and the Safety of U.S. Troops in Iraq: Hearing before the S. Democratic Policy Comm., 110th Cong. 2 (2008) (statement of Edwards Blacke, former KBR employee).

59. InSPECTOR Gen., U.S. DeP'T DeF., supra note 49, at 5-6.

60. The Task Force Restore Iraqi Oil (TF RIO) program was to restore Iraq's oil industry infrastructure. The U.S. Corps of Engineers (USACE ) was assigned the mission. USACE awarded KBR contract DACA63-03-D-0005. Id. at 1.

61. Id. at 12 .

62. Id. at 11 .

63. "Uncertainty is the imperfection in knowledge of the true value of a parameter for either an individual or a group." INST. MED., supra note 10, at 25. 
is incomplete or alarming. Covello, Sandman, and Slovic underscore that "in science there is never complete certainty, since new evidence can always overturn previous beliefs." ${ }^{64}$

Federal administrators need the flexibility in order to act swiftly in coordinated fashion particularly in times of national emergency under the leadership of a designated agency and agent but without compromising processes for human safety, public health, fiscal responsibility, or national security. This, in turn, requires transparency as to the risks of chemicals, data produced by manufacturers on a product's effect on health and the environment, the scientific protocols followed at every stage, the environmental assessments conducted, and the manufacturer's responsibility for hazards.

\section{B. Military}

Decisions of the armed forces are dependent on their specific mission; orders are delivered from the hierarchical top-level brass. Control is rigid and localized in a war theatre. Actors whose decisions in the management of environmental health risks manifest in complex feedback loops are the leadership in the federal agencies namely the U.S. Departments of Defense and Veterans Affairs, Congress, the judiciary. These actors traditionally manage risks within a unit system and closely follow fluctuations of information inputs; creative solutions are limited by real and assumed boundaries.

Modern warfare operations include armed forces from multiple nations and civilian contractors who may contribute to a chaotic environment by exercising their separate control and command responsibilities. Given a crisis, multiple rigid organizational structures and stakeholders within the U.S. government and outside each with their own policies, procedures, and techniques for risk assessment and incentives for risk management contribute to the range of unpredictable behaviors of the disparate actors. These organizational structures require simultaneous attention and chaos may be observed at the system level.

There were risk management processes in place when service members were exposed to Agent Orange and sodium dichromate. However, the processes were neither robust nor effective for the toxicity of the agents to which the members of the armed forces were exposed nor for the environment in which the armed forces were operating. ${ }^{65}$ The concerns raised by members of Congress to the handling of disability claims, the filing of the class-action lawsuit claiming cancers and birth defects were caused by Agent Orange, ${ }^{66}$ and the notification to

64. Vincent T. Covello, Peter M. Sandman \& Paul Slovic, Risk Communication, Risk Statistics, and Risk Comparisons: A Manual for Plant Managers: Part V Anticipating OBJECTIONS to EXPLANATIONS OF CHEMICAL Risks (1988).

65. U.S. Gov'T ACCOUnTABILITy OfFICE, supra note 31, at 9.

66. The class consisted of those persons who were in the United States, New Zealand or Australian Armed Forces at any time from 1961 to 1972 who were injured while in or near Vietnam by exposure to Agent Orange or other phenoxy herbicides, including those composed in whole or in part of 2,4,5-trichlorophenoxyacetic acid or containing some amount of 
the Coalition Joint Task Force 7 about the exposure to sodium dichromate acted as catalysts or drivers in the unstable environments prompting the retooling of risk management processes.

The U.S. Army Public Health Command released the 2013 Revision of the Environmental Health Risk Assessment and Chemical Exposure Guidelines for Deployed Military Personnel to "characterize operational risks from chemical exposures as consistently as possible, by use of a standardized process that is both scientifically supportable and militarily feasible." ${ }^{67}$ These guidelines include a range of deployment scenarios from a single catastrophic release of a chemical to a temporary exposure to a continuous environmental exposure in air, water, or soil. Similarly, the exposures may be intermittent, continuous, or simultaneous. ${ }^{68}$

Chemical Exposure Guidelines for Deployed Military Personnel are issued to provide military exposure guidelines (MEGs) to characterize health and mission risks in a deployment environment to chemical warfare agents (CWAs) and toxic industrial chemicals (TICs) ${ }^{69}$ Risk management decisions based on the (MEGs) are unique to the military population as chemical exposure data must be evaluated for both health and mission risks; the guidelines are a tool for a Commander to use for operational decisions. ${ }^{70}$ MEGs developed by the U.S. Army Public Health Command were adapted from existing federal standards, including that of the U.S. Environmental Protection Agency (USEPA) and the Agency for Toxic Substances and Disease Registry (ATSDR), and peer-reviewed toxicological estimates among others. ${ }^{71}$ Certain assumptions are made namely that the military population including Active Duty, Reserve, and National Guard, is "healthy and fit." 72 Although the guidelines assume no predisposing factors, the USAPHC acknowledges that "with increased reliance on National Guard and Reservists, an increased number of older personnel are now deployed" and there may be individuals who are susceptible to chemical exposures. ${ }^{73}$ Acknowledging genetic variability and individual susceptibility is essential. ${ }^{74}$ The MEGs represent conservative population thresholds and a single exposure rather than cumulative

2,3,7,8-tetrachlorodibenzo-p-dioxin. The class also includes spouses, parents, and children of the veterans born before January 1, 1984, directly or derivatively injured as a result of the exposure. In re "Agent Orange" Prod. Liab. Litig., 100 F.R.D. 718, 729 (E.D.N.Y. 1983) (certifying class).

67. U.S. ARmy Pub. Health Command, Environmental Health Risk Assessment and Chemical Exposure Guidelines for Deployed Military Personnel 2 (2013), https://phc.amedd.army.mil/PHC\%20Resource\%20Library/TG230-DeploymentEHRA-and-MEGs2013-Revision.pdf [https://perma.cc/3CY2-5YWJ]..

68. Id. at 4 .

69. Id. at 22-23.

70. Id. at $4,21$.

71. Id. at 10 .

72. Id. at $6,17$.

73. Id. at 17.

74. Id. 
effects of multiple deployments. ${ }^{75}$

\section{Response to Agent Orange Exposure}

The behavior of the military as an organization in its risk management efforts of Agent Orange was disjointed, haphazard, and uncoordinated. ${ }^{76}$ Not addressing the toxicity of the herbicide when deciding to utilize it for defoliation efforts as part of its mission, lack of record-keeping, controversy over data reliability of the evidence linking health risks to the exposure, and the confusion over responsibility for managing the risk were disastrous.

Indeed, in response to questions, Richard Danzig, Principal Deputy Assistant Secretary of DOD, in September 1979, said, "[e]ven today, there is no valid scientific evidence to support a causal relationship between low dosage exposure and unspecific human diseases of delayed onset." that "described herbicide orange as "relatively nontoxic to man or animals.""78

Although mission requests were approved by the military chain of command and the South Vietnamese government, "most helicopter missions and all truck, boat, and hand spraying were conducted at the discretion of unit commanders." 79 The chain of military command, the U.S. Embassy officials, members of the South Vietnamese government, the airmen in helicopters, and the soldiers on the ground were actors each operating in rigid control within their own leadership command yet together were contributing to the chaotic dynamics of a war environment. ${ }^{80}$

Science now shows that variables influencing the degree of exposure include the rate of biodegradation of herbicide orange, the drift of the sprayings from the targeted areas, and ground troop locations. ${ }^{81}$ Containment of the drift of herbicide orange influenced by climate as well as the speed and altitude of the aircraft was determined only after examination of widespread crop damage extending from one-two kilometers. ${ }^{82}$ Given the belief that herbicide orange was "relatively nontoxic to man or animals," no special safety precautions were taken to avoid exposure outside of Air Force handlers being advised to use gloves and face shields. ${ }^{83}$ The time period DOD advised between spraying and defoliation was four to six weeks to ensure successful defoliation and safety of ground troops, not to protect service members from toxic exposure, but rather from gunfire from

75. Id. at 18 .

76. U.S. Gov'T ACCOUNTABILITY OfFICE, supra note 31 , at 5.

77. Letter Richard Danzig, Principal Deputy Assistant Sec'y of Def, to William J. McCormick, Jr., Ass. Dir., Fed. Personnel and Compensation Div., U.S. Gen. Accounting Office 2 (Sept. 4, 1979).

78. U.S. Gov'T AcCOUnTABILITy OfFICE, supra note 31, at 4.

79. Id.

80. Id.

81. Id. at 6 .

82. Id. at 6-7.

83. Id. at 4 . 
fighter surveillance aircrafts. ${ }^{84}$ Even with DOD's guidance, however, "chemical officers confirmed that no restrictions [actually] were placed on entering sprayed areas." ${ }^{\circ 5}$ Indeed, contrary to the DOD maintaining that "exposure was very unlikely since DOD personnel did not enter a sprayed area until approximately 4 to 6 weeks after the mission when defoliation was complete," a time span of six weeks, the GAO investigation revealed that troop commanders merely "were asked to keep troops clear of the area during the spraying mission."

Numerous federal agencies shared responsibility for the oversight and risk of the exposure effects of TCDD. The Agent Orange Working Group designated in 1981 by the White House included the DOD, VA, Health Education and Welfare (HEW), Agriculture and EPA. ${ }^{87}$ In addition, the Departments of Agriculture, Interior, and HEW exercised their authority in April 1970, to suspend certain uses of 2,4,5-T in most herbicide applications recognizing that 2,4,5-T was a teratogen. ${ }^{88}$ Each of these agencies, however, operated independently with their own leadership, unique statutorily mandated missions, and separate appropriated federal budgets, thereby creating an environment of frustration on the edge of chaos with little evidence of information feedback among the agencies to adapt to change nimbly.

As early as 1970, Congress mandated the DOD to seek the National Academy of Sciences (NAS) to study the ecological and physiological effects of the use of herbicides in South Vietnam. ${ }^{89}$ The NAS recommended in 1974 that "further intensive studies are especially required with reference to the ecological distribution, the pharmacology mechanism of toxicity, possible mutagenicity, and carcinogenicity of TCDD and its possible teratogenicity in man." ${ }^{90}$ Despite the National Academy of Science's recommendation for a long-term study, not only did the Department of Defense determine that no epidemiological study would be undertaken, ${ }^{91}$ they did not issue "any instructions to its medical facilities to monitor complaints of illness possibly resulting from herbicide exposure." ${ }^{92}$

In fact, there were no accurate DOD military records of service members' deployment locations that would establish proximity to health risk. Finally, in 1978, the VA began compiling an Agent Orange Registry by offering medical

\section{Id. at 5 .}

85. Id.

86. Id. at 4-5.

87. Agent Orange Review (Veterans Admin., D.C.), Aug. 1983, at 1, https://www. publichealth.va.gov/docs/agentorange/reviews/ao_newsletter_aug83.pdf [https://perma.cc/9EL7HCRT].

88. U.S. Dep't Veterans Affs., Vietnam Veterans and Agent Orange Exposure: InDEPENDENT Study Course, 3 (2002), https://stlawco.org/data/files/Departments/Veterans/ AgentOrangeData/VHIagentorange.pdf [https://perma.cc/3KX3-2PKZ].

89. Act of Oct. 7, 1970, Pub. L. No. 91-441, 84 Stat. 905, 913 (1970).

90. U.S. Gov'T AcCountability OfFICE, supra note 27, at 5.

91. Id. at 2 .

92. Id. at 6 . 
exams to those who may have been exposed. Through September 2018, 690,302 initial exams and 81,926 follow up exams had been provided. ${ }^{93}$

The Agent Orange class-action lawsuit filed in 1979 on behalf of service members injured by exposure to Agent Orange and their families sought relief through the judicial system against the major manufacturers of herbicides used in the Vietnam War after the victims had been neither recognized nor compensated for their injuries by the military or VA. ${ }^{94}$

A $\$ 180$ million out of court settlement was settled in $1984 .{ }^{95}$ Nine years after the payment program was initiated, the fund was depleted; approximately 52,000 veterans received cash payments averaging about $\$ 3,800 .{ }^{96}$ In 2003 , the U.S. Supreme Court failed to broaden the settlement with a deadlocked vote. ${ }^{97}$

The result of this lawsuit was as a catalyst for Congress to enact legislation authorizing the VA to conduct an epidemiological study, for the White House to establish the Interagency Work Group to Study Possible Long-Term Health Effects of Phenoxy Herbicides, and the VA to establish the Advisory Committee on Health-Related Effects of Herbicides. ${ }^{98}$

93. Bill Outlaw, Calling all Vietnam Veterans: It's to Your Benefit to Join the Agent Orange Registry, U.S. DEP'T VETERANS AFFS., https:/www.publichealth.va.gov/exposures/publications/ agent-orange/agent-orange-2018/ao-registry.asp [https://perma.cc/7NSH-DMW2].

94. See In re "Agent Orange" Prod. Liab. Litig., 818 F.2d 145, 148-152 (2d Cir. 1987) (providing history of the litigation), aff'd 597 F. Supp. 740 (S.D.N.Y. 1984) (approving settlement between plaintiffs and chemical companies). See also In re "Agent Orange" Prod. Liab. Litig., supra note 66. (Certifying the class, which consisted of those persons who were in the United States, New Zealand or Australian Armed Forces at any time from 1961 to 1972 who were injured while in or near Vietnam by exposure to Agent Orange or other phenoxy herbicides, including those composed in whole or in part of 2,4,5-trichlorophenoxyacetic acid or containing some amount of 2,3,7,8-tetrachlorodibenzo-p-dioxin. The class also includes spouses, parents, and children of the veterans born before January 1, 1984, directly or derivatively injured as a result of the exposure).

95. Agent Orange Settlement Fund, U.S. DeP'T Veterans AfFS., https://www.benefits.va. gov/compensation/claims-postservice-agent_orange-settlement-settlementFund.asp [https://perma.cc/TG97-L9ST]. In re "Agent Orange” Prod. Liab. Litig., 597 F. Supp. 740, 748 (E.D.N.Y. 1984)."Pursuant to the stipulation of settlement, defendants have agreed to pay to the class $\$ 180$ million plus interest.”

96. Id.

97. Although Justice John Paul Stevens recused himself without reason, it was reported that his son with cancer died in 1996, at 46 years. Gina Holland, Court Deadlocks on Agent Orange, CBS News (Jan. 9, 2003), https://www.cbsnews.com/news/court-deadlocks-on-agent-orange/ [https://perma.cc/96UR-ZUDP].

98. The Veterans Health Programs Extension and Improvement Act, P.L. 96-151, 93 Stat. 1092; Agent Orange Review, supra note 87, at 1. (the Interagency Work Group consisted of HHS (lead agency); White House Office of Policy Development; White House Office of Science and Technology Policy; Office of Management and Budget; Council of Economic Advisors; EPA; Departments of State, Agriculture, Labor, Veterans Administration, and ACTION); DeP'T OF Veterans Affairs, Vietnam Veterans and Agent Orange Exposure: IndePendent Study COURSE 1, 2 (2002), https://www.stlawco.org/data/files/Departments/Veterans/AgentOrangeData/ 

HEALTH CHALLENGES

This epidemiological study and Workgroup were not successful. The government did not intend to include ground troops in their study of long-term medical effects linking only herbicide handlers and aircraft crewmembers to exposure, remarkably, even though the DOD acknowledged ground troops' exposure. ${ }^{99}$ The VA failed in its efforts to design the research protocol on the long term effects of dioxin; CDC was transferred the responsibility for leading the study. ${ }^{100}$ And, the CDC was burdened with its own challenges in acquiring exposure data from military records and self-reports. While an Agent Orange Validation Study was attempted, CDC found the military records lacking to conduct the large epidemiologic study. ${ }^{101} \mathrm{CDC}$ efforts were halted after advisory boards and panels concluded, "the Congressionally mandated Agent Orange Study was improbable."102

Responsiveness to service members with policy changes that could address and support their health care needs was delayed by uncertainty. Attentiveness to symptoms of a disease to confirm a service-connected disability was delayed by the absence of documentation linking proximity to the chemical agent ${ }^{103}$ and science demonstrating causal effect between exposure and disease. ${ }^{104}$ "Epidemiologic studies on Agent Orange are historically burdened by the lack of reliable exposure data. The lack of accurate data remains a continued source of frustration for researchers, government officials, and Vietnam-era veterans seeking conclusive information on the health risks of exposure to Agent Orange." 105

VHIagentorange.pdf [https://perma.cc/38DD-8ZLQ].

99. Comptroller General of the United States. U.S. Ground Troops in South Vietnam Were In Areas Sprayed with Herbicide Orange. Letter from Comptroller General of the U.S. Elmer B. Staats, to Senator Charles Percy, Permanent Subcommittee on Investigations, Committee on Governmental Affairs. FPCD-80-23, November 16, 1979, at 9.

100. Sidath Viranga Panangala,, Cong. Research Serv., RL34370, Veterans Affairs: Health Care and Benefits for Veterans Exposed to Agent Orange 6 (2008).

101. Id.

102. Id. at 10 .

103. U.S. Gov't Accountability Off., FPCD-80-23, U.S. Ground Troops IN South Vietnam Were in Areas Sprayed with Herbicide Orange 1 (1979).

104. See Nat'l Acads. of Scis Eng'g \& Med, Veterans and Agent Orange: Update 11 12-14 (2018). "There are many questions regarding veterans' health that cannot be adequately answered by examining superficially analogous exposures and outcomes in other populations. It is only through research on veterans themselves that the totality of the military service experience can be properly accounted for." Id. at 15. See also Inst. OF MED., COMM. ON THE ASSESSMENT OF Wartime Exposure to Herbicides in Viet., Characterizing Exposure of Veterans to Agent Orange and Other Herbicides Used in Vietnam (1997). "Different approaches have been used in estimating the exposure of Vietnam veterans and these studies generally rely on selfreported exposures, records-based exposure estimates, or biomarkers of TCDD exposure. Each of these approaches is limited in its ability to determine precisely the degree of individual exposure."

105. Sidath Viranga Panangala \& Douglas Reid Weimer, Cong. Research Serv., 
The institutional rules associated with risk management proved to be limiting factors restricting change. The various actors self organized into their own silos with unique cultures, priorities, and resources creating barriers to changing the rules. Focused on the military mission, the DOD's goal was on herbicide effectiveness at defoliation and crop destruction. Courts struggled to adjudicate numerous lawsuits; the settlement did not reach all veterans exposed; Congressional legislators balked at billion-dollar appropriations to the federal budget for claims.

In 1991, twenty years after exposure, the Agent Orange Act was enacted by Congress to require the VA to determine the association between the presenting disabilities and an herbicide agent. ${ }^{106}$ This legislation established for the first time the "presumption" of service connection with increased risk of diseases associated with herbicide exposure. ${ }^{107}$ As evidence of transformational policy change, the Agent Orange Act also mandated the NAS Institute of Medicine to undertake comprehensive biennial reviews of the evidence of health problems that may be linked to exposure to Agent Orange and other herbicides used during the Vietnam War to determine whether there is a statistical association between the suspect diseases and herbicide exposure, taking into account the strength of the scientific evidence. ${ }^{108}$

As significant as the Agent Orange Act legislation was hailed, however, VA took until August 31,2010, to promulgate its final regulation with publication in the Federal Register allowing presumption of exposure for veterans serving in Vietnam between January 9, 1962, and May 7, 1975. ${ }^{109}$ In announcing the new rule for health care and disability compensation benefits some thirty-five years after the end of the conflict, the VA Secretary Eric Shinseki remarked, "It was the right decision, and the President and I are proud to finally provide this group of Veterans the care and benefits they have long deserved." 110 Twenty-eight thousand claims were decided by the VA in the first six weeks of processing disability compensation applications based on the new regulation. ${ }^{111}$

RL34370, Veterans Affairs: Health Care and Benefits for Veterans Exposed to Agent ORANGE 11 (2010).

106. Agent Orange Act of 1991, 38 U.S.C. $\$ 1116$ (2018). §1116(a)(3). Herbicide agent was defined as "a chemical in an herbicide used in support of the United States and allied military operations in the Republic of Vietnam during the period beginning on January 9, 1962, and ending on May 7, 1975."

107. PANANGALA \& WeIMER, supra note 105 , at 3.

108. NAT'L ACAD. SCI. ENG'R \& MED., supra note 28, at 2.

109. Diseases Associated with Exposure to Certain Herbicide Agents (Hairy Cell Leukemia and Other Chronic B-Cell Leukemias, Parkinson's Disease and Ischemic Heart Disease), 75 Fed. Reg. 53,202 (Aug. 31, 2010) (codified at 38 CFR 3.309).

110. Press Release, U.S. Dep't Veterans Aff., VA Publishes Final Regulation to Aid Veterans Exposed to Agent Orange, (Aug. 30, 2010), https://www.va.gov/opa/pressrel/pressrelease. cfm?id=1945 [https://perma.cc/5HUB-9CZA].

111. Press Release, U.S. Dep't Veterans Aff, VA Processes First Claims for New Agent Orange Presumptives (Dec. 17, 2010), https://www.va.gov/opa/pressrel/pressrelease.cfm?id=2022 

HEALTH CHALLENGES

Ultimately, the executive branch through the VA managed the risk and ensured scalability and reach by continuing to promulgate additional regulations for presumptive eligibility for disability compensation to include new conditions based on scientific evidence reported by NAS. ${ }^{12}$ This coordination among Congress in enacting the Agent Orange Act, the NAS in investigating the statistical association between science and illness, and the VA in promulgating regulations led to the payment through August 2011 of over $\$ 2.2$ billion in retroactive benefits to 89,000 veterans. ${ }^{113}$ This is evidence of a non-linear system in vital contact with multiple environments responding to chaos.

The government and military's risk management response to exposure of Agent Orange demonstrated a gross failure over decades for leadership protecting their individual missions to react in a coordinated, comprehensive, and timely manner. This comprehensive effort was long delayed. It took the energy of the advocacy movement and elected officials on behalf of victims to shake the equilibrium of an inert system to produce transformational management of the exposure of service members to Agent Orange.

\section{Response to Sodium Dichromate Exposure}

The United States shifted from primarily a full-time active command force during the Vietnam War to a reserve component of a part-time active force. In 2010, 25 to 30 percent of the U.S Central Command forces were the Reserve Component. ${ }^{114}$ Indeed, the National Guard soldiers at Qarmat Ali Water Treatment Plant were part-time, not full-time, soldiers who were deployed in an environment not to fight a war but to serve as the security force for KBR, a private contractor working on restoring the water treatment plant at Basra, Iraq. ${ }^{115}$ This all-volunteer military capability and increase in reserve forces contribute to the chaotic behavioral dynamics of the sodium dichromate matter.

Coincident to the decrease in full-time active command force has been an increase in the reliance of contractors for site security and logistical support, tasks the Inspector General for Iraq Reconstruction admitted formerly were provided by active-duty forces. ${ }^{116}$ The IG concluded that "contracting in a hostile/combat

[ https://perma.cc/WZD6-GJEC].

112. PANANGALA \& WeIMER, supra note 105 , at 4.

113. Press Release, U.S. Dep’t Veterans Aff. Over \$2.2 Billion in Retroactive Agent Orange Benefits Paid to 89,000 Vietnam Veterans and Survivors for Presumptive Conditions (Aug. 31, 2011), https://www.va.gov/opa/pressrel/docs/AgentOrangePresumptivesNR.doc [https://perma.cc/ T2FD-HZVU].

114. U.S. DeP't Def., QuAdrennial Defense ReVIEw 93 (2010).

115. Inspector Gen., U.S. Dep't of Defense, Exposure to Sodium Dichromate at Qarmat Ali Iraq in 2003: Part I - Evaluation of Efforts to Identify, Contact, and Provide Access to CARe for Personnel 2 (2010).

116. Statement before the House Subcomm. on Nat'l Sec. and Foreign Affairs, Comm. on Oversight and Gov't Reform,111th Cong. (June 29, 2010) (statement by Stuart W. Bowen, Jr. 
environment is much more difficult and far more vulnerable" and there are "significant shortfalls in most aspects of contractor oversight." 117 Although the dynamics surrounding the armed forces may be tightly monitored, the forces at work among the contractors' activities are less certain. Congressman Earl Blumenauer, advocating for declassification of the KBR contract on behalf of Oregon national guardsmen exposed to sodium dichromate, said, "I remain concerned that KBR's contract may be much more loosely drawn, removing incentives for the contractor to behave responsibly and exposing taxpayers to enormous liability and our troops to harm." 118

With thousands of sites within Iraq, environmental risk assessments by the Army pre-deployment to sites other than those on "major bed down locations" were considered impracticable. ${ }^{19}$ Quoting a March 2009 letter from Army Secretary Pete Geren, U.S. Senator Evan Bayh testified, "[o]rdinarily, the Army would perform an environmental assessment of a site prior to deployment of service members or contractors to that site. In this case, however, the number of sites (approximately 4,000) over the geographic area of Iraq potentially needing occupational health assessments in the immediate aftermath of hostilities, combined with the need to restore critical infrastructure as soon as possible, made this impracticable." 120 The DOD Inspector General concluded that "KBR did not fully comply with applicable occupational safety and health standards required by the contract, and TF RIO failed to enforce contractor compliance." ${ }^{121}$ An environmental risk assessment of the Qarmat Ali site prior to the service members' arrival was neither performed by the Army nor interpreted as required by KBR. ${ }^{122}$

Linear communication of concerns raised and decisions by the contractors and the military operating within their own silos without feedback created a time delay in identifying and confirming exposure. On May 31, 2003, KBR representatives became aware of the use of sodium dichromate. ${ }^{123}$ On August 7, 2003, samples of air and soil/sediment from various areas were collected by KBR; duplicate samples were collected two days later. ${ }^{124}$ The August 7 \& 9,

Inspector General, Office of the Special Inspector General for Iraq Reconstruction).

117. Id.

118. Elana Schor, Military Contractors Were Granted Legal Indemnity for Hazardous Substances, N.Y. TIMES (Dec. 3, 2010), https://archive.nytimes.com/www.nytimes.com/gwire/ 2010/12/03/03 greenwire-military-contractors-were-granted-legal-indemn-58060.html [https://perma.cc/2Y3U-S4K6].

119. Letter from Pate Geren, Sec'y of the Army to Evan Bayh, Senator, U.S. Senate (March 2, 2009).

120. The Exposure at Qarmat Ali: Did the Army Fail to Protect U.S. Soldiers Serving in Iraq?: Hearing Before the S. Democratic Policy Comm., 111th Cong. (Aug. 3, 2009) (statement of Sen. Evan Bayh).

121. Inspector Gen., U.S. DeP'T DeF., supra note 49, at 12.

122. See id. at 9,33 .

123. Id.

124. Id. at 41 . 

HEALTH CHALLENGES

2003, Team RIO Qarmat Ali Site Assessment Trip Memo and material safety data sheet documented the purpose of the trip to be "Limited Environmental Assessment of Soils Potentially Contaminated with Sodium Dichromate at the Qarmat Ali Water Treatment Plant." KBR personnel and KBR subcontractor personnel were advised that entry was restricted and until laboratory analyses were received. ${ }^{125}$ An Environmental Health and Safety assessment was recommended to be completed to confirm "potential environmental health issues are identified and addressed." 126 Also, minutes of a KBR staff meeting held August 8, 2003, included "serious health problem at water treatment plant with a chemical called Sodium Dichromate. ${ }^{127}$ Almost $60 \%$ of people now exhibit the symptoms." Although these are ominous notes, the minutes characterized "[t]here is no reason for shutting down the water station." 128

As evidence of complex communication feedback loops, U.S. Task Force RIO Contracting Officer officially was informed of the potential soil contamination on August 8, 2003, ${ }^{129}$ but it was not until almost five years later in June 2008 when the Department of Veterans Affairs learned of the exposure. ${ }^{130}$ KBR required their subcontractor employees working in some areas to wear Personal Protective Equipment (PPE) in August 2003.131 the wearing of PPE by all coalition personnel was not required until October 17, 2003. "On September 15, 2003, the Combined Forces Land Component Command Surgeon's office notified [the U.S. Army Public Health Command Provision] CHPPM of the potential exposure." ${ }^{132}$ Although the U.S. soldiers were exposed months earlier, access to the site was not restricted to them until September 19, 2003. ${ }^{133}$

DOD readily admits the need to improve its occupational and environmental health surveillance activities including monitoring and documentation of

125. Memorandum from Johnny Morney, John Dipple \& Steve Kegelman on KBR's Qarmat Ali Water Treatment Site Assessment for the Limited Environmental Assessment of Soils Potentially Contaminated with Sodium Dichromate 4-5 (2003) (on file with author) [hereinafter Qarmat Ali Water Treatment Site Assessment Memo]. The Materials Safety Data Sheet on sodium dichromate accompanying the memo outlined major health hazards for inhalation.

126. Id. at 5 .

127. Team RiO, Minutes of Meeting: Meeting Number MOME03808 1 (2003) (on file with author).

128. Id. Minutes also indicated, "[s] odium dichromate could have been dumped on the ground for quite a long time. We do not know how deep it is but it looks like it is greater than 4 feet . . . Medical test every individual working in the area to assess level of exposure." Id. at 1-2.

129. Inspector Gen., U.S. DeP'T DeF., supra note 49, at 12.

130. Letter from Eric K. Shinseki, U.S. Sec'y of Veterans Affairs, to John D. Rockefeller, IV, U.S. Senator from W. Va. 1 (Oct. 8, 2009).

131. Qarmat Ali Water Treatment Site Assessment Memo, supra note 125, at 5.

132. InSPECTOR Gen., U.S. DeP'T OF Defense, supra note 115, at 3.

133. Memorandum from the Def. Health Bd. to LTG Eric B. Schoomaker, Surgeon Gen. of the Army 7 (Dec. 10, 2008) [hereinafter Memorandum to Schoomaker]. 
hazardous occupational and environmental incidents. ${ }^{134}$ "The Services, including our commanders on the ground, have learned their lessons well pertaining to the need to fully characterize deployed environmental settings for possible exposures to hazardous materials and to ensure that the data is archived for future use." ${ }^{135}$

After KBR health, safety, and environmental staff detected "elevated hexavalent chromium concentrations" at the Qarmat Ali plant, they "encapsulated various soil areas with a layer of liquid asphalt and loose gravel aggregate."136 This action, unfortunately, eliminated medical impact pre-encapsulation which could have demonstrated more accurate results. ${ }^{137}$ Indiana National Guard and Department of Army civilians on site received serum and red blood cell testing for whole chromium, urine testing, pulmonary function testing, and chest $\mathrm{x}$-rays within 30 days of last potential exposure and within 30 days of remediation of the site after the end of potential exposure. ${ }^{138}$ The U.S. Center for Health Promotion and Preventive Medicine (CHPPM) Incident Response in October of 2003 initiated site sampling and medical testing for Indiana Army Reserve National Guard and Department of Army civilians. ${ }^{139}$ CHPPM reported that "nearly all test results were below the detection limit" concluding "there was not a significant inhalation exposure from chromium VI." 140

Learning lessons from the experience of Agent Orange was mixed. On the one hand, the government having the SMART-PM arrive soon after the notification of the incident shows a responsiveness to sodium dichromate exposure that was not evident with Agent Orange. On the other hand, even today, there is neither agreement as to the degree of exposure of the individual National Guard members nor the effects of the toxicity of sodium dichromate to those

134. Id. at 3 .

135. Statement before the House Committee on Government Reform Subcommittee for National Security, Emerging Threats and International Relations 6 (July 19, 2005) (statement of Michael E. Kilpatrick, Deputy Dir. of Deployment Health Support Directorate, Dep't of Def).

136. Memorandum to Schoomaker, supra note 134, at 4. The Defense Health Board stated, "[t]he decision by the USACHPPM assessment team not to provide medical exams to the entire available Qarmat Ali population in 2003 represents a lost opportunity for obtaining more complete knowledge of the possible medical impact of pre-encapsulation exposure." INSPECTOR GEN., U.S. DEP'T OF DEFENSE, supra note 49, at 22.

137. InSPECTOR GEN., U.S. DeP'T DeF., supra note 49, at 22.

138. See Memorandum to Schoomaker, supra note 134 at 3, 10.

139. See Coleen Baird Weese, Evaluation of Exposure Incident at the Qarmat Ali Water Treatment Plant, ARMY MeD. DeP'T J. 10,10 (2009) https://ufdc.ufl.edu/AA00062689/00014 [https://perma.cc/JY2H-8444] (the Special Medical Augmentation Response Team-Preventive Medicine (SMART-PM) deployed "consisted of industrial hygienists, occupational medicine physicians, and environmental scientists" to do the testing).

140. U.S. Army Ctr for Health Promotion and Preventive Med., Update on Sodium Dichromate Exposure at Qarmat Ali Water Treatment Plan in 2003 (For Soldiers) 2 (2008), https://www.dpc.senate.gov/hearings/hearing49/september_2008_chppm_qarmatali_fact_ sheet.pdf [https://perma.cc/G5XZ-GGS2]. 

HEALTH CHALLENGES

exposed. ${ }^{141}$ This is remarkable as it demonstrates that the military has not learned from its experience with Agent Orange and especially its ongoing failure to recognize the importance of critical medical records. Site location and exposure timelines are powerful drivers of access to both health care and epidemiology, and documenting that information is extraordinarily important. But with a rigid organization, inefficient processes, and significant time lapse, the medical records of the National Guard were not accessible and "remained scattered throughout the medical records system;" paper medical records were sent from the unit to the mobilization site and returned to the unit following deployment. ${ }^{142}$ Completeness of the medical records could not be assured with soldiers serving in multiple locations and redeployment with different units.

Absent accurate records to link service members' symptoms to the chemical hazard, a special Medical Surveillance Program was established for veterans with exam results tracked in the Gulf War Registry. ${ }^{143}$ "We have the names and contact information of all National Guard members present at Qarmat Ali. We have also verified the numbers of these Veterans who have received a Gulf War Registry (GWR) examination." "144 This learning from Agent Orange documents proximity to risk and health status.

It is unfortunate that the DOD and VA have been challenged with incremental rather than transformational change to coordinate across missions and agencies to modernize their separate health records. ${ }^{145}$ The Departments of DOD and VA fiercely have defended the privacy of their individual records preventing coordination across the mission and silos leading to sluggish incremental policy changes. ${ }^{146}$ "Inevitability does not mean easy transition." 147 The U.S. House of Representatives Committee on Veterans Affairs in 2013 delivered a mandate to President Obama, "[s]elect a system, pick a path and move forward. We can no longer waste the time or money that will result from endless bureaucratic

141. See Inspector Gen., U.S. DeP't Def., supra note 49, at 16.

142. Id. at $17,22-33$.

143. See Paul Ciminera, Michael J. Superior \& Tim Bullman, Findings from the Department of Veterans Affairs Qarmat Ali Medical Surveillance Program, 181 Military Medicine 307, 310 (2016) ("The overall low participation rate in the VA medical surveillance program of $15 \%$ severely compromises any generalization from this limited number of participants to the entire cohort of potential exposed Veterans.”).

144. Letter from Eric K. Shinseki, Sec'y, Dep't of Veterans Affairs, to John D. Rockefeller IV, Senator, U.S. Senate 1 (Oct. 8, 2009).

145. See U.S. Government Accountability Office, GAO-11-265, Electronic Health Records: DOD ANd VA Should Remove BARriers ANd IMProve EFForts to MeEt their COMmon SYstem NeEds (2011).

146. See id.

147. Agency for Healthcare Research and Quality, No. 14-0041-EF, A Robust HeAlth DAta InfRAStRUCTURE 1 (2014) https:/digital.ahrq.gov/sites/default/files/docs/ publication/a-robust-health-data-infrastructure.pdf [https://perma.cc/PN5Y-6UB9]. 
inaction." ${ }^{148}$ Finally, the VA is launching in spring 2020 the initial installation of the new Electronic Health Record Modernization (EHRM) program with interoperability with DOD and community care providers to enable the sharing of patient information eliminating the manual transfer of records. ${ }^{149}$ The completion date, however, is $2028 .{ }^{150}$

The tolerance of risk of the KBR military contractors and the United States military differ based on their mission and relationship to the environment. The DOD Inspector General in 2011 concluded that the DOD response to the contamination "lacked urgency and was incomplete. The delay may have occurred as a result of mission prioritization with the Command." ${ }^{151}$ The former U.S. Army V Corps Commander explained, "[y]our focus changes completely, and you are either going to take your eye off the tactical fight in order to deal with the operational issues, or you are going to ignore the operational issues and stay involved in the tactical fight." ${ }^{152}$ The KBR Health, Safety and Environmental (HSE) Coordinator supporting RIO noted soil and air samples "showed extremely high levels of hexavalent chromium in the soil" yet low levels of chromium in the air, explained with tests being conducted not "during one of the frequent dust storms in which all of the materials on the ground became airborne." 153 The Coordinator believed "the plant was a highly dangerous and unsafe and contaminated facility;" 154 he left his duties shortly thereafter.

Brown and Root Services was awarded the contract on March 8, 2003. On March 20, 2003, Task Order 3, "Emergency Response Tasks for Iraq Oil Reconstruction" was executed and was classified when published. ${ }^{155}$ The "Administrative Contracting Officer had minimal, if any, opportunity to review the contract language once they deployed" and absent a classified computer system, discussions were precluded "between the Administrative Contracting

148. Letter from Members of the House Veterans Committee, to Barack Obama, President of the U.S. (May 22, 2013).

149. Veterans ask, VA answers: Questions on electronic health record modernization, Veterans AfFAirs: VANTAge Point (Jan. 19, 2020), https://www.blogs.va.gov/VAntage/70571/ veterans-ask-va-answers-questions-electronic-health-record-modernization/ [https://perma.cc/HAG5-WZE4].

150. Id.

151. InSPeCtor Gen., U.S. DePARtment of DefEnSe, supra note 49, at 16.

152. Id.at 17.

153. The Exposure at Qarmat Ali: Contractor Misconduct and the Safety of U.S. Troops in Iraq: Hearing before the S. Democratic Policy Comm., supra note 58.

154. Id. at 5.

155. To increase transparency and contractor accountability on indemnification agreements, the National Defense Authorization Act of 2013, Section 865, requires certain DOD contract provisions to be reported to Congress. Wyden NDAA Amendment to Hold Contractors Accountable Sent to the President, Ron Wyden SEnAtor For Oregon (Dec. 21, 2012). https://www.wyden. senate.gov/news/press-releases/wyden-ndaa-amendment-to-hold-contractors-accountable-sent-tothe-president [https://perma.cc/P7TV-2LM8]. 
Officer and the contractor concerning contract language." 156 The DOD IG concluded that the contract language was impractical. ${ }^{157}$ The language also was misinterpreted; "TF RIO and KBR considered facilities to be ready for the contractor to begin work if they were free of military hazards" interpreting "benign" to mean "safe to operate from a security standpoint."158 "This indicated all parties disregarded the "industrial" part of "environmental hazards" included in Task Order 3." 159

Numerous legal challenges have been filed on behalf of service members seeking damages based on privately concealing risk and negligence among other allegations. These include:

- Forty-seven Indiana National Guardsmen filed a federal lawsuit alleging $\mathrm{KBR}$, Inc. privately concealed risk and "exposing them to a substantially heightened risk of cancer and other life-threatening illnesses." Although plaintiffs argued that they would return to "Indiana, where they would subsequently experience health problems, such as cancer and kidney damage," the court granted defendants' motion to dismiss for lack of personal jurisdiction. ${ }^{160}$

- Following a three-week U.S. District Court trial, twelve Oregon National Guardsmen were awarded $\$ 85$ million; each was to receive $\$ 850,000$ in noneconomic damages and $\$ 6.25$ million in punitive damages for "reckless and outrageous indifference."161 The judge, however, "trimmed compensatory damages for each soldier to $\$ 500,000$ because he determined Oregon law required the reduction." ${ }^{162}$ KBR was successful in its appeal of the jury verdict by the 9th U.S. Circuit Court of Appeals arguing the trial court did not have personal jurisdiction; the case was referred back to Oregon district court. ${ }^{163}$

- In turn, KBR filed suit against the United States in U.S. Court of Federal Claims, alleging the indemnification clause in its contract was to protect KBR against " "unusually hazardous' risks" in Iraq; therefore, the government

156. Inspector Gen., U.S. Department of Defense, supra note 49, at 9.

157. Id. at 7. Task Order 3, paragraph 1.1.1 of the contract stated: "No earlier than the day after the Ground Forces secure an Iraq Oil Infrastructure facility, contractor personnel shall be notified by ACO that benign conditions exist."

158. Id at 8 .

159. Id.

160. McManaway v. KBR, Inc., 695 F. Supp. 2d 883, 887, 893, 896 (S.D. Ind. 2010).

161. Bixby v. KBR, Inc., No. 3:09-CV-632-PK, 2013 WL 1789792, (D. Or. Apr. 26, 2013), aff'd, 2013 WL 12204397 (D. Or. June 4, 2013), rev'd and remanded, 603 Fed. App'x 605 (9th Cir. 2015).

162. Joany Carlin, KBR verdict: Judge affirms $\$ 81$ million of damages awarded to 12 Oregon soldiers for toxic exposure in Iraq, OREGONIAN (Apr. 26, 2013), https://www.oregonlive.com/ health/2013/04/kbr_verdict_judge_affirms_most.html [perma].

163. Bixby v. KBR, Inc., 603 Fed. App'x 605, 606 (9th Cir. 2015). 
should be liable for the judgment along with their attorney's fees. ${ }^{164}$

Congressional legislation was introduced, recognizing that future exposures are likely to occur, to advocate for medical evaluations of service members, to investigate the association between science and illness, and to increase accountability and transparency in defense contracts. In 2009, Senator Evan Bayh introduced the Health Care for Members of the Armed Forces Exposed to Chemical Hazards Act, ${ }^{165}$ and the Health Care for Veterans Exposed to Chemical Hazards Act ${ }^{166}$ guided by government's response to Agent Orange in Vietnam to shift the evidentiary burden to receive medical care and to authorize a scientific review of the evidence linking all future exposures of "occupational and environmental health chemical hazards of particular concern" to adverse health effects. ${ }^{167}$ In addition, in 2012, Senator Ron Wyden authored a provision adopted in the National Defense Authorization Act to require the DOD "to justify to Congress the need for indemnification" clauses in DOD contracts. ${ }^{168}$

The Defense Health Board in its external review to address the potential sodium dichromate exposure said, "minimizing illness and injury from these sources or from the concomitant battle hazards requires not only the usual industrial hygiene approach, but also a judicious approach that balances the costs and benefits of incurring exposure at an industrial site and avoiding hazards of the battle environment." 169

\section{SHIFTING PARADIGM}

In spite of the sense of urgency to determine the association between potential exposure and disease incidence, change is inhibited by organizational policies, culture, political climate, and limited government resources, to say nothing of the scientific realities around the state of knowledge and technology. ${ }^{170}$

164. Kellogg Brown \& Root Servs., Inc. v. United States, 115 Fed. Cl. 46, 49 (2014). While the Court of Claims dismissed this lawsuit on grounds that it lacked jurisdiction over the claims presented, the Armed Services Board of Contract Appeals subsequently held that KBR was entitled to indemnification. See Kellogg Brown \& Root Services, Inc., ASBCA Nos. 59357, 59358 (Aug. 13, 2015).

165. S. 642, 111 th Congress (2009)

166. S. 1779, 111 th Cong. (2009).

167. Press Release, Evan Bayh, Senator for Indiana, Bayh: Indiana Soldiers Exposed to Toxic Chemicals in Iraq Deserve Expanded VA Care (August 3, 2009).

168. Press Release, Ron Wyden United States Senator for Oregon, The Wyden-Authored Provision was Included in the Final House-Senate Conference Agreement and Passed by Both Houses (Dec. 21, 2012), https://www.wyden.senate.gov/news/press-releases/wyden-ndaaamendment-to-hold-contractors-accountable-sent-to-the-president [https://perma.cc/JEM7-UUK8].

169. Memorandum to Schoomaker, supra note 134, at 8.

170. Pamela A. Mischen \& Stephen K. Jackson, Complexity Theory and Public Administration: The Role of Organizations and Organizational Networks in Policy Implementation, Paper presented at the Conference of the Public Administration Theory in Harrisburg, PA (May 26, 2007) at 14. 
New approaches to risk management by the executive branch should be developed for transformational change. Authorizing a scientific review of the evidence linking exposure to chemicals of particular concern to adverse health effects, establishing a registry of service members potentially harmed, shifting the burden of evidence from the injured to the government, and requiring front line commanders to report hazardous material exposure to their non-deployed headquarters should be considered.

The legislative branch could impact risk management as well. Rather than continue to legislate relief from harm by name of the war, geographic location of incident, calendar years, or health consequence/disease that excludes service members from eligibility to benefits, new legislative language should recognize that risk is inherent with military service. Legislation should provide the flexibility federal administrators require to act swiftly in coordination with stakeholders in times of national emergency without compromising processes for human safety, environmental threats, public health, fiscal responsibility, enforcement, and national security.

Federal courts have a role to play in risk management. The Judicial branch must assess Congressional legislative intent, the Executive branch's management of risk, and the scientific evidence from experts. Courts play an important role in determining reasonableness. Courts wrestle with determining compensation for health and environmental harms, deciding causation, and evaluating scientific evidence competently. ${ }^{171}$ Science must be translated within the confines of statutory authority and administrative regulation leaving some stakeholders dissatisfied with the result. ${ }^{172}$ All of this requires the judiciary to keep up to date with scientific knowledge in order to conclude which scientific evidence is valid and to balance risks with benefits.

Reforms in the executive and judicial branches are needed. Only the Congress, however, can clarify these questions from the public health perspective through enacting or amending legislation to articulate the role of the government, manufacturers, administrators, contractors, and the taxpayers to ensure risk is fairly shared in the United States.

Environmental challenges should be explored openly rather than trying to assign blame and sanction, and strategies for intervention could be distributed over the system. A veteran's own report of exposure and inclusion on a registry, for example, should be sufficient proof to receive medical evaluations unless there is evidence to the contrary. Moving away from a performance management approach of blame and sanction removes risk management out of the adversarial and costly judicial environment.

Considering the challenges experienced with the exposure to Agent Orange and sodium dichromate, policy recommendations are identified. Implementation

171. Peter S. Menell, The Limitations of Legal Institutions for Addressing Environmental Risks, 5 J. ECON. PersP. 93, 99-100 (1991).

172. See Milton Russell \& Michael Gruber, Risk Assessment in Environmental Policy-Making, 236 SCIENCE 286, 286 (1987). 
of these recommendations listed from greatest impact could shift the paradigm from managerial control to monitoring information; from rigid and localized control to control distributed over the system; and from blame and sanction to problems explored openly:

- Establish a single uniform contracting process for use during contingency operations ${ }^{173}$ with a new integrated office and a working group from relevant federal agencies for planning and execution. ${ }^{174}$

- Develop and require joint planning in operational settings among the armed forces, contractors, and Army Corps of Engineers to ensure prompt identification and comprehensive mitigation of environmental risks. ${ }^{175}$

- Ensure the classification of documents balances the need for security with timely dissemination to meet the health care needs of service members and other stakeholders, to facilitate communication, and to reduce distrust. ${ }^{176}$

- Condense the implementation schedule from 2028 to 2025 for the Electronic Health Record Modernization (EHRM) program's replacement of the current Veterans Health Information Systems and Technology Architecture (VistA) system.

- Enact legislation that provides a veteran's inclusion on a registry to be "recognized as sufficient proof to receive medical care barring evidence to the contrary shifting the evidentiary burden to the federal government."177

- Require the inclusion in EHRM all deployment date(s), location, and job assigned during deployment; potential exposures to chemicals of concern; and status of health information generated as a result of exposure. ${ }^{178}$

- Require DOD to create, keep current, and permanently maintain registries of all service members who are deployed. The registries should include date(s), location, and job assigned during deployment; potential exposures to chemicals of concern; and status of health information generated as a result of exposure. ${ }^{179}$

- Re-examine and revise MEGs to reflect multiple deployments and to recognize the variability of the general population who serve in the armed forces. ${ }^{180}$

173. "The Contingency Support Plan for Repair and Continuity of Operations of the Iraqi Energy Infrastructure, dated January 31, 2003, stated the mission was to 'support the Commander, U.S. Central Command in the assessment of damage, repair, maintenance, resumption and/or continuity of the operations of the oil infrastructure of Iraq."' INSPECTOR GEN., U.S. DEPARTMENT OF DEFENSE., supra note 49, at 7.

174. Statement before the House Subcomm. on Nat'l Sec. and Foreign Affairs, Comm. on Oversight and Gov't Reform, supra note 116.

175. Memorandum to Schoomaker, supra note 134, at 3.

176. Id. at 3,9 .

177. The Exposure at Qarmat Ali: Did the Army Fail to Protect U.S. Soldiers Serving in Iraq?, supra note 120 , at 3 .

178. See Memorandum to Schoomaker, supra note 134, at 11.

179. See id. at 12.

180. U.S. ARmy Pub. Health Command, supra note 67, at 6, 21. 
- Require the Secretary of DOD to enter into agreements with the NAS for each incident of exposure that the Secretary of DOD determines is of particular concern to assess the strength concerning the association between the exposure to such hazard and acute and long-term health consequences of such exposure.

- Require the U.S. Army Public Health Command (Provision) to assess and confirm that individuals with a potential exposure have access to one primary contact to receive information on the nature of the exposure, to participate in appropriate medical surveillance programs, and to be referred to the proper specialty service. ${ }^{181}$

- Enact legislation at the state level to require all hospitals to ask the question, "Have you ever served in the military?" to ensure service members receive timely diagnoses and appropriate health care. ${ }^{182}$

- Review and revise competencies for hazard recognition training, comprehensive investigations, and risk communications for commanders. ${ }^{183}$

- Conduct an assessment to assure expertise exists in epidemiology and industrial toxicology among DOD and VA professionals, and identify individuals with a specific and broad spectrum of expertise to facilitate access to a consultation on risk assessment and risk management to relevant federal agencies. ${ }^{184}$

- Re-examine the Military Claims Act ${ }^{185}$ and the Federal Tort Claims Act ${ }^{186}$ to consider contractor participation in military deployments. ${ }^{187}$

\section{CONCLUSIONS}

"It is inevitable that military units will encounter potentially hazardous industrial sites during combat operations. The hazards encountered may pose risks of infectious disease, poisonings from industrial toxins, or injuries." 188

Environmental challenges that the military as a complex organization must confront and resolve cannot be broken down into discreet compartments to be addressed by individual disciplines. Given the timing of the mission, environmental risk assessments in a war zone may not be conducted, access to important and critical data may be hindered because of the prolific use of private

181. See Memorandum to Schoomaker, supra note 134 at, at 11.

182. See Am. AcAD. OF Nursing, Have you ever Served in the Military: A Service for America's Veterans by the American Academy of Nursing, HAVEYOUEVERSERVED.COM, http://www.haveyoueverserved.com/about.html [https://perma.cc/778C-SM24].

183. Memorandum to Schoomaker, supra note 134, at 12.

184. Id. at 3 .

185. 10 U.S.C. $\$ 2733$ (2018).

186. 28 U.S.C. $\S \S 1346,2680$ (2018).

187. See William Spyro Speros, Friend-of-a-Friendly Fire: A Future Tort Issue of Contractors on the Battlefield, 35 PuB. CONT. LAW J., 297 (2006).

188. Memorandum to Schoomaker, supra note 134, at 8. 
contractors, and the evaluation for both health and mission risks limit risk management options. In an environment in which our national security may depend on timely and accurate decisions, relationships among agents, and positive feedback in interactions are essential.

Determining the strategy for risk communication to inform the public about a potential risk while tolerating their fear is a challenge for public officials. ${ }^{189}$ For the public to accept risk, public officials have an enormous task to ensure that their policies can be characterized as credible and fair. The perception of risk depends on trust that the information provided is evidence based, accurate, thorough, and honest. The perception of risk is dependent on whether it is considered voluntary or involuntary. ${ }^{190}$ Public officials have a particular challenge of communicating risk associated with policy options during emergencies and when balancing options that are neither strictly beneficial nor strictly harmful. The "goal is not to change people's opinions about controversial environmental issues. The goal is to change the way we discuss these issues, make the discussions accurately reflect the risks we face and the available options, and enable us to make effective decisions, " 191 For the public, however, to determine their own tolerance of risk, they must have uncertainties acknowledged. ${ }^{192}$ "Scientists must be willing to take a larger role in explaining the risks to the public, including the uncertainties inherent in any risk assessment."193

Congressional legislation, federal statutes, and executive courage may not yet be calibrated appropriately to provide the flexibility federal administrators require when acting swiftly in times of national emergency without compromising processes for human safety, fiscal responsibility, and national security. A new model for risk management for service members who have been exposed to complex occupational and environmental chemicals applying complexity theory may be required. Advancing beyond a "multiple-single uncertainty factor system" that assumes "estimates of health protection benefit can be juxtaposed with the costs of health protection measures," is necessary. ${ }^{194}$ The complexity of knowledge begs for non-linear understanding.

Complexity theory can help us understand how organizations function and

189. Peter M. Sandman, Crisis Communication Best Practices: Some Quibbles and Additions. 34 J. Applied Comm. Res. 257, 258 (2006).

190. Christopher J. Daggett, The Role of Risk Communication in Environmental Gridlock, in Effective Risk Communication: The Role and Responsibility of Government and Nongovernment Organizations 31, 32 (Vincent T. Covello, Peter M. Sandman, and Paul Slovic eds, 1989).

191. Id. at 35 .

192. Vincent T. Covello, Peter M. Sandman, \& Paul Slovic, Risk Communication, Risk Statistics, and Risk Comparisons: A Manual for Plant Managers, in EFFECTIVE RisK Communication: The Role and Responsibility of Government and Nongovernment Organizations 297, 329 (Vincent T. Covello, Peter M. Sandman, \& Paul Slovic eds, 1989).

193. William Ruckelshaus, Science, Risk and Public Policy, 221 ScI. 1026, 1028 (1983).

194. Inst. of Med., Environmental Health Sciences Decision Making: Risk Management, Evidence, And Ethics: Workshop Summary 4 (2009). 

HEALTH CHALLENGES

encourage new perspectives working in both non-linear and non-vertical processes across agencies to create new relationships for transformational change. Agents' behavioral responses are dependent on past experience. However, adaptation and evolution, indeed, are possible as greater receptivity to smaller procedural changes could result in larger impacts. Recognizing that stakeholders in the public policy process approach risk management differently, the infrastructure that enables the executive judicial and legislative branches and their agents to respond appropriately to chemical exposure demands reform. Creating an environment that promotes innovation and rapid problem solving is essential. "As energy flows between agents, conditions change, and create a state of nonequilibrium. This dissipative transfer of energy allows for movement, interaction and reaction to the environment." 195

Joint risk management planning efforts must be refined anticipating the next emergency when neither medical expertise nor chemical mixture experience is available to assess risk, recordkeeping is lacking, proof of exposure is questionable, and the relationship of the chemical hazard and the health effect is not certain. Such a new model would establish a registry of those potentially harmed, an independent entity that could conduct a scientific review of the evidence linking certain medical conditions to exposure and a shift of the burden of evidence from the injured to the government. The development of uniform standards for the electronic exchange of health information among the U.S. Departments of Defense, Veterans Affairs, and Health and Human Services and community health care providers would facilitate not only the provision of health care but enhance the identification of emerging diseases and health threats. ${ }^{196}$

The military is influenced by its hierarchy of agents or actors whose behavior and interactions act as the catalyst for the organization to self-organize. However, agents may be restricted by limiting mechanisms that diminish possibilities for change within or external to its networks. ${ }^{197}$ "Each population has its own history, culture, and socioeconomic structures." 198 The military as an institution is unique in that all decisions of the armed forces are dependent on its specific mission. As

195. Pamela A. Mischen \& Stephen K. Jackson, Complexity Theory and Public Administration: The Role of Organizations and Organizational Networks in Policy Implementation. Paper presented at the Conference of the Public Administration Theory in Harrisburg, PA (May 26, 2007) at 18.

196. See Statement before the House Comm. on Gov't Reform, Subcomm. for Nat'l Sec., Emerging Threats and Int'l Relations, 109th Cong. 6, 13, 17 (2005) (statement of Michael E. Kilpatrick, Deputy Director, Deployment Health Support Directorate Department of Defense).

197. Pamela A. Mischen. Complexity Theory and Public Administration: The Role of Organizations and Organizational Networks in Policy Implementation. Paper Presented at the Conference of the Public Administration Theory Network in Harrisburg, PA (May 26, 2007), at 14.

198. Neil Pearce \& Franco Merletti, supra note 2. 
such, the risk management processes are an integral component of this unique complex adaptive system.

"Risk Management is not an add-on feature to the decision-making process but rather a fully integrated element of planning and executing operations. . . Risk management helps us preserve combat power and retain the flexibility for bold decisive action. Proper risk management is a combat multiplier that we can ill afford to squander."

General D.J. Reimer, Chief of Staff Army, 1995 (DA 1998) ${ }^{199}$

199. U.S. Army Ctr for Health Promotion and Preventive Med., USAChPPM Technical Guide 230: Chemical Exposure Guidelines for Deployed Military Personnel 3 (2003). 